\title{
PERAN PROFITABILITAS DALAM MEMEDIASI PENGARUH INFLASI DAN STRUKTUR MODAL TERHADAP HARGA SAHAM
}

\author{
I Made Ivan Adiwinata ${ }^{1}$ \\ Ni Ketut Purnawati ${ }^{2}$ \\ ${ }^{1}$ Fakultas Ekonomi dan Bisnis Universitas Udayana (Unud), Bali, Indonesia \\ E-mail:madeivan47@gmail.com
}

\begin{abstract}
ABSTRAK
Penelitian ini bertujuan untuk menguji dan menganalisis pengaruh secara langsung, pengaruh tidak langsung dan pengaruh total antara inflasi dan struktur modal terhadap harga saham melalui return on Asset (ROA). Sampel penelitian ini adalah perusahaan pertambangan sub sektor batubara periode 2013-2017 dengan menggunakan metode sampling sensus. Terdapat 17 perusahaan yang memenuhi kriteria sebagai sampel penelitian. Teknik analisis pada penelitian ini adalah analisis jalur. Pengumpulan data dilakukan dengan metode observasi non partisipan yaitu melalui data laporan keuangan yang dipublikasikan pada website www.idx.co.id dan data inflasi pada website www.bi.go.id. Berdasarkan hasil penelitian ini menunjukkan bahwa Inflasi dan struktur modal berpengaruh negatif dan signifikan terhadap ROA dan harga saham, ROA berpengaruh positif dan signifikan terhadap harga saham. Hasil dari uji sobel menunjukkan ROA mampu memediasi secara signifikan pengaruh inflasi dan struktur modal terhadap harga saham.

Kata Kunci: inflasi,profitabilitas,struktur modal, harga saham
\end{abstract}

\section{ABSTRACT}

This study aims to examine and analyze the direct effect, indirect influence and total influence between inflation and capital structure on stock prices through return on assets (ROA). The sample of this study is the coal sub-sector mining company for the period 20132017 using the census sampling method. There are 17 companies that meet the criteria as research samples. The analysis technique in this study is path analysis. Data collection is done by non-participant observation method, namely through financial report data published on the website www.idx.co.id and inflation data on the website www.bi.go.id. Based on the results of this study indicate that inflation and capital structure have a negative and significant effect on ROA and stock prices, ROA has a positive and significant effect on stock prices. The results of the sobel test show that ROA is able to significantly mediate the effect of inflation and capital structure on stock prices.

Keywords: inflation, profitability, capital structure, stock price 


\section{PENDAHULUAN}

Memaksimalkan nilai perusahaan adalah tujuan utama dari manajemen keuangan (Wiagustini, 2014:9). Nilai perusahaan yang tinggi tercermin dari harga sahamnya. Harga saham adalah harga yang terjadi di pasar modal yang ditentukan oleh pelaku pasar dan ditentukan oleh permintaan dan penawaran di pasar modal Jogiyanto, (2015:8). Semakin tinggi harga saham, maka nilai perusahaan tersebut juga akan tinggi, sehingga dapat memaksimalkan kekayaan pemegang saham (Rani dan Dianita, 2015) dan hal ini juga mencerminkan tingkat kepercayaan investor yang tinggi pada perusahaan yang mengeluarkan saham tersebut (Purnama dan Purbawangsa, 2017).

Harga saham merupakan harga saat ini dari pendapatan yang akan diterima investor di masa depan. Harga saham yang digunakan dalam transaksi di pasar modal adalah harga yang terbentuk pada mekanisme pasar permintaan dan penawaran pasar (Muniarti, 2016). Saham yang banyak diminati oleh investor akan mengalami kenaikan harga saham sedangkan sebaliknya saham yang kurang diminati akan mengalami penurunan harga sahamnya (Jogiyanto, 2015:110). Permintaan dan penawaran saham di pasar modal akan menyebabkan harga saham berflukuasi setiap harinya, selain itu faktor ekonomi makro yang meliputi suku bunga, inflasi, nilai tukar, PDB dan kinerja keuangan yang terermin dari rasio keuangan perusahaan juga akan mempengaruhi harga saham.

Beberapa penelitian sebelumnya inflasi dipandang sebagai variabel makroekonomi yang paling mempengaruhi harga saham, karena inflasi merupakan indikator yang secara langsung dikendalikan melalui kebijakan 
moneter. Vanita dan Arnav (2014) menyatakan adanya hubungan negatif yang signifikan antara indeks harga saham dengan tingkat inflasi. Perubahan dalam inflasi mampu mempengaruhi aktivitas perdagangan dalam pasar modal yang akan berpengaruh terhadap permintaan dan penawaran suatu saham.

Secara fundamental harga suatu jenis saham dipengaruhi oleh kinerja perusahaan dan kemungkinan risiko yang dihadapi perusahaan. Menurut Wiagustini (2014:77) rasio keuangan perusahaan dikelompokan menjadi lima bagian yaitu rasio likuiditas, rasio leverage / struktur modal, rasio profitabilitas, rasio aktivitas, rasio penilaian/pasar. Kelima rasio tersebut digunakan sesuai dengan tujuan analisis yang dilakukan terhadap perusahaan. Dalam penelitian ini menggunakan rasio leverage / struktur modal dan profitabilitas, tujuannya adalah untuk mengetahui bagaimana hubungan antara harga saham dengan kinerja perusahaan. Penelitian terdahulu yang dilakukan oleh Kristanti dan Triaryati, (2012) menunjukkan bahwa rasio tersebut yang paling dominan mempengaruhi harga saham.

Inflasi merupakan suatu kejadian yang menggambarkan situasi dan kondisi di mana harga barang mengalami kenaikan dan mata uang mengalami pelemahan. Jika kondisi ini terjadi secara terus menerus, akan berdampak pada semakin buruknya kondisi ekonomi secara menyeluruh (Kusuma dan Badjra, 2016). Naiknya tingkat inflasi ditandai dengan harga barang naik, biaya produksi lebih tinggi dari pendapatan dan profitabilitas perusahaan akan menurun. Penurunan pendapatan mempengaruhi investor untuk berpikir bahwa saham perusahaan tersebut kurang kompetitif. Sahroni dkk. (2017) menyatakan inflasi yang tinggi 
akan menyebabkan tingginya suku bunga bank. Suku bunga tinggi akan memicu tingginya suku bunga utang yang pada akhirnya akan menurunkan laba bersih perusahaan. Perusahaan yang mengalami penurunan laba bersih cenderung tidak membagikan deviden, hal ini menyebabkan investor kehilangan ketertarikan berinvestasi pada perusahaan tersebut dan akan berdampak pada penurunan volume transaksi penawaran dan permintaan terhadap saham perusahaan terebut di pasar modal, sehingga menurunkan harga saham perusahaan tersebut.

Hasil penelitian Vanita dan Arnav (2014) menyatakan adanya hubungan negatif yang signifikan antara indeks harga saham dengan tingkat inflasi, penelitian dengan hasil yang sama juga diperoleh oleh Lindayanti dan Dewi (2015) menyatakan inflasi berpengaruh negatif signifikan terhadap harga saham. Berbeda dengan hasil penelitian yang diperoleh Perera (2015) menyatakan bahwa tingkat inflasi tidak berpengaruh signifikan dalam menentukan indeks harga saham.

Inflasi dapat meningkatkan biaya produksi dan menurunkan volume produki suatu perusahaan Irham (2016:61). Peningkatan biaya produksi lebih tinggi daripada pendapatan perusahaan mengakibatkan profitabilitas dari perusahaan tersebut mengalami penurunan yang juga akan menurunkan harga saham perusahaan tersebut (Tandelilin, 2010:343).

Teori tersebut menunjukkan inflasi berpengaruh negatif signifikan terhadap profitabilitas, dan didukung oleh hasil penelitian dari Hooshyari dan Moghanloo (2015); Lindayanti dan Dewi (2015); Duraj dan Moci (2015) menyatakan inflasi berpengaruh negatif signifikan terhadap profitabilitas, namun hasil penelitian 
yang berbeda diperoleh Wibowo, (2012) inflasi tidak memiliki pengaruh terhadap profitabilitas.

Struktur modal merupakan kombinasi antara hutang dan ekuitas yang digunakan perusahaan dalam membiayai kegiatan operasionalnya (Bringham dan Houston, 2011:155). Menurut Fahmi (2016:185) struktur modal adalah gambaran dari bentuk proporsi finansial perusahaan yaitu antara modal yang dimiliki bersumber dari utang jangka panjang dan modal sendiri menjadi sumber pembiayaan perusahaan. Perusahaan yang komposisi hutangnya lebih dominan dibandingkan ekuitasnya cenderung memiliki resiko yang lebih tinggi, resiko yang tinggi akan menurunkan laba perusahaan dan diikuti oleh penurunan harga sahamnya (Sahroni dkk., 2017). Sruktur modal dalam penelitian ini diproksikan dengan DER. Debt to equity ratio (DER) adalah rasio atau perbandingan antara ekuitas yang dimiliki perusahaan dengan hutang. Hutang muncul karena perusahaan tidak dapat memenuhi semua ekuitas yang mereka butuhkan hanya dari ekuitas yang dimiliki atau dari ekuitas penjualan saham, sehingga perusahaan harus mencari ekuitas tambahan melalui hutang.

Secara umum, semakin besar angka DER dianggap perusahaan tersebut memiliki risiko finansial. DER yang besar berarti perusahaan tersebut membiayai investasinya dengan komposisi hutang yang lebih banyak dibandingkan dengan modal, sehingga akan timbul resiko perusahaan tersebut gagal membayar kewajibanya dan suku bunga yang tinggi akan mengurangi profit perusahaan, sehingga harga saham perusahaan tersebut menurun (Ulzanah dan Murtaqi, 2016). Semakin besar jumlah DER untuk suatu perusahaan maka manajemen harus 
bekerja lebih keras untuk menjaga arus kas perusahaan. Umunya investor di pasar modal cenderung menghindari perusahaan dengan nilai DER yang tinggi, sehingga harga saham perusahaan tersebut menurun.

Pernyataan tersebut didukung oleh hasil penelitian Velnampy dan Niresh (2012) dimana Struktur modal berpengaruh negatif signifikan terhadap harga saham, tetapi hasil yang berbeda justru diperoleh oleh Gatuht dkk. (2016) dimana struktur modal tidak berpengaruh terhadap harga saham.

Soedarsa dkk. (2015) menyatakan besarnya tingkat rasio DER berarti perusahaan memiliki risiko yang lebih tinggi karena menunjukkan bahwa perusahaan masih memerlukan hutang untuk menutupi semua aktivitas operasionalnya. Perusahaan yang tidak mampu menggunakan hutangnya dengan optimal akan berdampak pada menurunya pendapatan perusahaan tersebut, oleh karena itu manajemen perusahaan harus bekerja keras untuk menjaga cashflow perusahaan.

Bukti empiris menunjukkan bahwa struktur modal mempunyai pengaruh negatif terhadap profitabilitas suatu perusahaan. Hal ini sesuai dengan hasil penelitian dari Ashraf dkk. (2017); Mahardhika dan Marbun (2016) dimana struktur modal berpengaruh negatif signifikan terhadap profitabilitas. Hasil penelitian yang berbeda diperoleh oleh Purwitasari (2013) struktur modal tidak berpengaruh terhadap profitabilitas.

Penurunan harga saham yang disebabkan pengaruh langsung inflasi dan struktur modal, kenyatanya disertai juga dengan penurunan kemampuan perusahaaan dalam menghasilkan laba bersih atau profitabilitas, pernyataan ini 
didukung oleh penelitian yang dilakukan oleh Duraj dan Moci (2015) bahwa inflasi dan struktur modal berpengaruh negatif signifikan terhadap profitabilitas. Profitabilitas adalah kemampuan perusahaan memperoleh laba atau keuntungan dengan tingkat asset tertentu Sartono (2012:122). Profitabilitas diproksikan oleh return on assets (ROA), ROA adalah rasio yang mengukur kemampuan perusahaan untuk menghasilkan laba bersih di bawah tingkat aset tertentu (Hanafi, 2012:81). Semakin tinggi ROA perusahaan, maka harga saham perusahaan tersebut juga akan meningkat, artinya Semakin besar kemampuan perusahaan dalam menghasilkan laba maka akan menarik minat investor untuk berinvestasi pada perusahaan tersebut, hal ini mengakibatkan harga saham dari perusahaan meningkat (Damar dkk., 2015).

Pernyataan ini didukung oleh hasil penelitian dari Kohansal dkk. (2013); Murniati (2016); Haque dan Faruquee (2013) yang menunjukkan bahwa profitabilitas memiliki pengaruh positif dan signifikan terhadap harga saham, namun hasil yang berbeda oleh Sahroni dkk. (2017) profitabilitas berpengaruh negatif signifikan terhadap harga saham.

Inflasi menyebabkan biaya produksi perusahaan akan meningkat, perusahaan akan menurunkan volume produksinya sehingga bedampak pada penurunan kemampuan perusahaan menghasilkan laba. Inflasi juga meningkatkan suku bunga hutang yang mengakibatkan penurunan laba bersih, sehingga perusahaan memutuskan tidak membagikan dividen. Investor tidak tertarik berinvestasi dan lebih memilih menjual sahamnya sehingga menurunkan harga saham perusahaan tersebut. Dapat disimpulkan bahwa inflasi berpengaruh 
terhadap ROA, dan nilai ROA akan mempengaruhi harga saham perusahaan tersebut. Winarti, (2018) menyatakan profitabilitas dapat memediasi pengaruh inflasi terhadap harga saham.

Perusahaan yang mampu mengoptimalkan dan mengelola hutangnya dengan baik yang digunakan untuk kegiatan operasional perusahaan, maka akan meningkatan laba yang diperolehnya, sebaliknya apabila peusahaan tidak mengelola hutangnya dengan baik akan berakibat pada menurunya penjualan dan laba yang diperoleh perusahaan. Investor di pasar modal yang tidak menyukai resiko akan cenderung menghindari perusahaan yang memiliki nilai DER yang tinggi, sehingga permintaan akan saham perusahaan tersebut di pasar modal menurun yang mengakibatkan harga saham perusahaan juga akan menurun. Penelitian yang dilakukan Hamidy dkk. (2015) menunjukkan profitabilitas mampu memediasi pengaruh struktur modal terhadap harga saham.

Indonesia adalah salah satu negara penghasil dan eksportir batubara terbesar di dunia setelah China, Amerika Serikat dan Australia. Harga saham perusahaan pertambangan batu bara pada tahun 2016 sampai dengan 2017 berfluktuatif namun masih relatif stabil, dikarenakan permintaan akan komoditi batu-baru meningkat tiap tahunya. Pada tahun 2013 sampai dengan tahun 2015 harga saham perusahaan sub sektor pertambangan batu-bara rnenurun drastis dikarenakan kenaikan harga komoditi batu-bara, seperti yang terlihat pada tabel 1.

Tabel 1 menjelaskan dari sepuluh emiten hampir seluruhnya mengalami penurunan harga saham pada tahun 2014 sampai dengan 2015. Saham Indo Tambang Darma Henwa Tbk (DEWA) tercatat mengalami penurunan harga 
saham yang paling besar dibandingkan saham emiten yang lainya yaitu Rp. 1424,per lembar saham menjadi Rp. 433,- per lembar, namun pada tahun 2016 harga saham hampir seluruh emiten juga mengalami kenaikan yang cukup signifikan.

Tabel 1.

Harga Saham Perusahaan Pertambangan Batu-bara (Closing Price)

\begin{tabular}{ccrrrrr}
\hline \multirow{2}{*}{ NO } & KODE & \multicolumn{5}{c}{ HARGA SAHAM (Rp / lembar) } \\
\cline { 1 - 4 } $\mathbf{1}$ & PERUSAHAAN & $\mathbf{2 0 1 3}$ & $\mathbf{2 0 1 4}$ & $\mathbf{2 0 1 5}$ & $\mathbf{2 0 1 6}$ & $\mathbf{2 0 1 7}$ \\
\cline { 3 - 6 } $\mathbf{2}$ & ADRO & 639 & 534 & 1326 & 4188 & 10829 \\
$\mathbf{3}$ & ARII & 334 & 262 & 742 & 493 & 340 \\
$\mathbf{4}$ & ATPK & 469 & 441 & 1669 & 1620 & 1236 \\
$\mathbf{5}$ & BYAN & 235 & 167 & 513 & 788 & 1313 \\
$\mathbf{6}$ & DEWA & 1424 & 433 & 1720 & 1863 & 1572 \\
$\mathbf{7}$ & HRUM & 883 & 488 & 2059 & 2208 & 1901 \\
$\mathbf{8}$ & PTRO & 1345 & 925 & 290 & 720 & 1660 \\
$\mathbf{9}$ & PTBA & 416 & 305 & 190 & 1939 & 3370 \\
$\mathbf{1 0}$ & SMMT & 1464 & 633 & 452 & 1882 & 2556 \\
\hline Sumber & TOBA & 720 & 369 & 2636 & 2980 & 4510 \\
\hline
\end{tabular}

Saham Petrosea Tbk (PTRO) yang sempat mengalami penurunan harga saham yang drastis pada tahun 2015 yaitu Rp. 925,- per lembar saham yang sebelumnya pada tahun 2013 harga sahamnya Rp. 1345,- per lembar saham, namun pada tahun 2017 mengalami kenaikan menjadi Rp. 1660,- per lembar. Hal ini disebabkan pada tahun 2013 sampai dengan tahun 2015 harga komoditi batu bara mengalami penurunan sehingga beberapa emiten batu bara menghentikan proses produksinya dan hal ini berdampak pada kondisi fundamental perusahaan yang mengakibatkan harga saham emiten batu bara turun drastis, namun seiring berjalanya waktu sektor industri pertambangan batu bara mulai mengalami pertumbuhan kembali, hal ini dikarenakan kenaikan harga komoditi batu bara yang disebabkan oleh meningkatnya permintaan akan komoditas batu bara oleh China dan India, selain itu permintaan akan komoditi batu bara juga ditopang dari 
dalam negeri, sejalan dengan proyek infrastruktur yang masih berlangsung sepanjang tahun sampai dengan tahun 2019.

Seiring dengan tren meningkatnya harga komoditi batu bara, kinerja keuangan emiten batu baru juga ikut meningkat, sehingga pertumbuhan harga saham sektor ini tumbuh secara perlahan namun pasti, hal ini menyebabkan banyak investor tertarik untuk berinvestasi pada sektor ini, namun hal tersebut belum menjamin harga saham akan terus meningkat, karena harga saham emiten sektor pertambagan batu bara cenderung mengalami fluktuasi yang cukup tinggi yang dipengaruhi faktor makro seprti inflasi, PDB, nilai tukar, dan juga dipengaruhi oleh kemampuan internal perusahaan yaitu kinerja keuangan mereka. Investor membutuhkan strategi analisis investasi yang matang untuk berinvestasi pada sektor industri ini.

Tingginya tingkat inflasi erat kaitannya dengan keadaan ekonomi yang terlalu panas. Permintaan atas produk yang melebihi penawaran mengakibatkan harga suatu barang cenderung naik. Tingginya tingkat inflasi mengakibatkan menurunnya daya beli masyarakat dan mengurangi pendapatan riil yang diterima oleh perusahaan (Tandelilin, 2010).

Meningkatnya tingkat inflasi yang ditandai harga barang naik, biaya produksi lebih tinggi dari pendapatan dan profitabilitas perusahaan akan menurun. Penurunan pendapatan dan profitabilitas perusahaan mempengaruhi investor untuk berpikir bahwa saham perusahaan tersebut kurang kompetitif. Sahroni dkk. (2017) menyatakan inflasi yang tinggi akan menyebabkan tingginya suku bunga bank. Suku bunga tinggi akan memicu tingginya suku bunga utang yang pada 
akhirnya akan menurunkan laba bersih perusahaan. Penurunan laba bersih perusahaan, termasuk deviden juga akan berdampak pada penurunan harga saham. Silva, (2016); Kusuma dan Badjra (2016); Soedarsa dkk. (2015); Arifin (2014) dan Subing (2016) menyatakan inflasi memiliki hubungan negatif signifikan dengan harga saham.

$\mathrm{H}_{1}$ : Inflasi berpengaruh negatif signifikan terhadap harga saham

Inflasi merupakan suatu kejadian yang menggambarkan situasi dan kondisi di mana harga barang mengalami kenaikan dan mata uang mengalami pelemahan. Jika kondisi ini terjadi secara terus menerus, akan berdampak pada semakin buruknya kondisi ekonomi secara menyeluruh. Inflasi secara relatif berpengaruh negatif terhadap harga saham karena inflasi meningkatkan biaya suatu perusahaan Irham (2016:61). Inflasi adalah kenaikan harga terhadap produk secara menyeluruh, inflasi merupakan sinyal negatif bagi para investor Asmara dan Suarjaya (2018). Semakin besar tingkat inflasi yang ditandai dengan naiknya harga-harga barang sehingga dapat menurunkan volume produksi perusahaan yang akan dapat menurunkan tingkat laba atau profitabilitas. Perusahaan yang mengalami penurunan laba bersih akan mengambil keputusan untuk tidak membagikan dividen, hal ini akan menurunkan minat investor untuk berinvestasi. Penurunan laba perusahaan akan membuat harga saham perusahaan juga turun (Tandelilin, 2010:343).

Teori tersebut menunjukkan inflasi berpengaruh negatif signifikan terhadap profitabilitas, dan didukung oleh hasil penelitian dari Hooshyari dan Moghanloo (2015); Lindayanti dan Dewi (2015); Duraj dan Moci (2015) menyatakan inflasi 
berpengaruh negatif signifikan terhadap return on asset (ROA), hasil penelitian yang sama juga diperoleh Kalengkongan, (2013) dan Kusuma, (2016) inflasi memiliki pengaruh negetif signifikan terhadap return on asset (ROA).

$\mathrm{H}_{2}$ : Inflasi berpengaruh negatif signifikan terhadap profitabilitas

Aspek sturktur modal mencerminkan kemampuan perusahaan memenuhi kewajiban finansialnya baik dalam jangka pendek maupun jangka panjang dan dapat pula mengukur seberapa banyak perusahaan dibiayai oleh hutang atau pinjaman (Wiagustini, 2014:85). Struktur modal dalam penelitian ini diukur menggunakan DER. Secara umum, semakin besar angka DER dianggap perusahaan tersebut memiliki risiko finansial. DER yang besar berarti perusahaan tersebut membiayai investasinya dengan komposisi hutang yang lebih banyak dibandingkan dengan modal, sehingga akan timbul resiko perusahaan tersebut gagal membayar kewajibanya dan suku bunga yang tinggi akan mengurangi profit perusahaan, sehingga harga saham perusahaan tersebut menurun.

Semakin besar jumlah DER untuk suatu perusahaan maka manajemen harus bekerja lebih keras untuk menjaga arus kas perusahaan. Penelitian dari Soedarsa dkk. (2015); Ulzanah dan Murtaqi (2015); Abditama dan Damayanti (2015); serta Ginting dan Munthe (2017) mendukung teori tersebut, dimana dinyatakan DER berpengaruh negatif signifikan terhadap harga saham.

$\mathrm{H}_{3}$ : Struktur modal berpengaruh negatif signifikan terhadap harga saham

Struktur modal merupakan kombinasi antara hutang dan ekuitas yang digunakan perusahaan dalam membiayai kegiatan operasionalnya (Bringham dan Houston, 2011:155). Menurut Fahmi (2016:185) struktur modal adalah gambaran 
dari bentuk proporsi finansial perusahaan yaitu antara modal yang dimiliki bersumber dari utang jangka panjang dan modal sendiri menjadi sumber pembiayaan perusahaan. Perusahaan yang komposisi hutangnya lebih dominan dibandingkan ekuitasnya cenderung memiliki resiko yang lebih tinggi, resiko yang tinggi akan menurunkan laba perusahaan dan diikuti oleh penurunan harga sahamnya (Sahroni dkk., 2017).

Jumlah atau angka DER yang semakin besar dalam perusahaan akan menghasilkan resiko lebih tinggi yang akan menurunkan laba, karena hutang yang melebihi ekuitas. Keuntungan yang lebih rendah akan menghasilkan nilai ROA yang lebih rendah, peningkatan nilai DER akan mengakibatkan penurunan nilai ROA.

Bukti empiris menunjukkan bahwa DER mempunyai pengaruh negatif terhadap ROA suatu perusahaan. Hal ini sesuai dengan hasil penelitian dari Ashraf dkk. (2017); Ulzanah dan Murtaqi (2015); Bonatua dkk. (2015); Mahardhika dan Marbun (2016) dimana DER berpengaruh negatif signifikan terhadap return on asset (ROA).

$\mathrm{H}_{4}$ : Struktur modal berpengaruh negatif signifikan terhadap profitabilitas

Rasio Profitabilitas adalah rasio yang bertujuan untuk mengetahui kemampuan perusahaan menghasilkan laba selama periode tertentu dan memberikan gambaran umum tentang efektivitas manajemen dalam menjalankan operasinya. Efektivitasnya bisa dilihat dari keuntungan yang dihasilkan pada perusahaan penjualan dan investasi. Profitabilitas diproksikan oleh return on asset (ROA), adalah rasio yang mengukur kemampuan perusahaan untuk menghasilkan 
laba bersih di bawah tingkat aset tertentu (Hanafi, 2012:42). Semakin tinggi ROA suatu perusahaan, maka akan semakin pula tinggi nilai aset perusahaan dan menyebabkan harga saham lebih tinggi, hal ini dikarenakan investor akan lebih tertarik berinvestasi pada perusahaan yang memiliki nilai ROA tinggi, investor menilai perusahaan memiliki prospek kinerja yang baik sehingga akan menguntungkan di masa depan. ROA berpengaruh positif signifikan terhadap harga saham Ini berarti bahwa aset perusahaan dapat mempengaruhi harga saham.

Teori tersebut didukung oleh hasil penelitian dari Kohansal dkk. (2013); Murniati (2016); Haque dan Faruquee (2013); Abditama (2015); Dwisona dan haryanto (2015) yang menunjukkan bahwa ROA memiliki pengaruh positif dan signifikan terhadap harga saham.

$\mathrm{H}_{5}$ : Profitabilitas berpengaruh positif signifikan terhadap harga saham.

Inflasi merupakan penurunan nilai uang atau naiknya harga barang dan jasa secara keseluruhan. Tingkat inflasi yang tinggi mencerminkan kondisi ekonomi suatu negara dalam kondisi yang tidak baik. Artinya kondisi ekonomi mengalami permintaan atas produk yang melebihi kapasitas penawaran produknya, sehingga harga - harga cenderung naik (Tandelilin, 2014:343). Biaya produksi perusahaan akan meningkat dikarenakan harga kebutuhan pokok dan bahan baku produksi. Perusahaan akan menurunkan volume produksinya sehingga bedampak pada penurunan kemampuan perusahaan menghasilkan laba.

Pernyataan ini didukung oleh hasil penelitian yang dilakukan Hooshyari dan Moghanloo (2015); Lindayanti dan dewi (2015); Duraj dan Moci (2015) inflasi berpengaruh negatif signifikan terhadap profitabilitas. Profitabilitas adalah 
kemampuan perusahaan untuk menghasilkan keuntungan atau laba yang diukur menggunakan rasio return on asset (ROA), ROA berpengaruh positif signifikan terhadap harga saham. Hasil penelitian yang sama dilakukan oleh Kohansal dkk. (2013), menemukan bahwa ROA memiliki pengaruh yang positif dan signifikan terhadap harga saham. Semakin tinggi ROA suatu perusahaan, maka semakin tinggi pula harga sahamnya, maka dapat diasumsikan ROA mampu memediasi pengaruh inflasi terhadap harga saham sesuai penelitian yang dilakukan oleh Winarti (2018); A'yun (2017) ROA mampu memediasi pengaruh inflasi terhadap harga saham.

$\mathrm{H}_{6}$ : Profitabilitas mampu memediasi pengaruh inflasi terhadap harga saham.

Struktur modal mengukur seberapa banyak perusahaan dibiayai oleh modalnya sendiri atau dengan hutang (Wiagustini, 2010:85). Struktur modal dapat diukur dengan menggunakan debt to equity ratio (DER). Bila perusahaan menggunakan hutangnya secara optimal maka akan menghasilkan profit yang semakin meningkat jika dibandingkan menggunakan modalnya sendiri. Penggunaan hutang dalam sumber pendanaan memiliki manfaat, seperti dapat mengurangi jumlah pembayaran pajak karena beban bunga tetap dapat mengurangi pembayaran pajak. Meningkatnya suku bunga dan perusahaan tidak mampu mengoptimalkan hutangnya untuk operasional perusahaan, maka perusahaan akan mengalami penurunan laba.

Nilai DER yang tinggi akan menurunkan laba perusahaan Ashraf dkk. (2017); Ulzanah dan Murtaqi (2015); Bonatua dkk. (2015) DER berpengaruh negatif signifikan terhadap profitabilitas. Perusahaan dengan nilai DER yang 
tinggi dianggap memiliki resiko finansial yang tinggi karena perusahaan beresiko tidak dapat membayar hutang tersebut akibat penurunan laba atau profitabilitas. Umumnya para investor akan menghindari perusahaan dengan nilai DER yang tinggi, sehingga nilai DER yang tinggi akan menurunkan harga saham suatu perusahaan, hal ini didukung oleh penelitian yang dilakukan oleh Abditama dan Damayanti (2015) yang menyatakan DER berpengaruh negatif signifikan terhadap harga saham. ROA memungkinkan memediasi pengaruh DER terhadap harga saham sesuai hasil penelitian yang diperoleh Misran dan Chabacib (2017); Hamidy dkk. (2015); Dwisona dan haryanto (2015) dan A'yun (2017) menyatakan ROA mampu memediasi pengaruh DER terhadap harga saham.

$\mathrm{H}_{7}$ : Profitabilitas mampu memediasi pengaruh struktur modal terhadap harga saham

\section{METODE PENELITIAN}

Penelitian ini dilakukan pada perusahaan sektor industri pertambangan batu bara yang terdaftar di Bursa Efek Indonesia periode 2013 - 2017 dengan mengakses situs www.idx.co.id. Populasi dalam penelitian ini adalah seluruh perusahaan industri pertambangan sub sektor batu bara yang terdaftar di BEI periode 2013-2017 yang sahamnya aktif diperjuabelikan dalam transaksi di pasar modal dengan jumlah 17 perusahaan. Teknik analisis dalam penelitian ini menggunakan analisis jalur.

Persamaan Sub-struktural 1

$$
\mathrm{Y} 1=\mathrm{py} 1 \mathrm{x} 1+\mathrm{py} 1 \mathrm{x} 2+\mathrm{e} 1
$$


Persamaan Sub-struktural 2

$\mathrm{Y} 2=\mathrm{py} 2 \mathrm{x} 1+\mathrm{py} 2 \mathrm{x} 2+\mathrm{py} 2 \mathrm{y} 1+\mathrm{e} 2$

Keterangan:

Y1=Profitabilitas

Y2=Harga Saham

$\mathrm{X} 1=$ Inflasi

$\mathrm{X} 2=$ Struktur Modal

$\mathrm{e} 1=$ Error of term atau variabel pengganggu pada variabel profitabiltas $\mathrm{e}=$ Error of term atau variabel pengganggu pada variabel harga saham $\mathrm{p}=$ koefisien korelasi

\section{HASIL DAN PEMBAHASAN}

Data yang telah diolah dan dihitung akan menunjukkan hasil analisis seperti Tabel 2 dan Tabel 3.

Tabel 2.

Hasil Analisis Jalur Persamaan Regresi 1

\begin{tabular}{lccccc}
\hline Model & $\begin{array}{c}\text { Unstandardized } \\
\text { Coefficients } \\
\text { B }\end{array}$ & Std. Error & $\begin{array}{c}\text { Standardized } \\
\text { Coefficients } \\
\text { Beta }\end{array}$ & T & Sig. \\
\hline 1 (Constant) & 4,176 & 0,169 & & 24,749 & 0,000 \\
Inflasi & $-0,210$ & 0,026 & $-0,621$ & $-8,043$ & 0,000 \\
DER & $-0,321$ & 0,064 & $-0,387$ & $-5,012$ & 0,000 \\
R12: 0,512 & & F & & Sig F: & \\
& & Statistik: & & 0,000 & \\
& & 42,985 & & \\
\hline
\end{tabular}

Sumber: Data diolah, 2018

Tabel 3.

Hasil Analisis Jalur Persamaan Regresi 2

\begin{tabular}{lccccc}
\hline Model & $\begin{array}{c}\text { Unstandardized } \\
\text { Coefficients } \\
\text { B }\end{array}$ & Std. Error & $\begin{array}{c}\text { Standardized } \\
\text { Coefficients } \\
\text { Beta }\end{array}$ & T & Sig. \\
\hline 1 (Constant) & 6,996 & 0,045 & & 154,253 & 0,000 \\
Inflasi & $-0,189$ & 0,003 & $-0,619$ & $-61,719$ & 0,000 \\
DER & $-0,200$ & 0,007 & $-0,253$ & $-29,567$ & 0,000 \\
ROA & 0,400 & 0,010 & 0,420 & 39,198 & 0,000 \\
R22: 0,995 & \multicolumn{7}{c}{ F } & & Sig F: & \\
& statistik: & & \\
& 5925,157 & & \\
\hline
\end{tabular}

Sumber: Data diolah, 2018 
Hasil pengujian pada Tabel 2 diperoleh nilai koefisien signifikan $0,000 \leq$ 0,05. Hasil tersebut menunjukkan bahwa Inflasidan DER berpengaruh secara simultan terhadap ROA. Hasil pengujian pada Tabel 3 diperoleh nilai koefisien signifikan $0,000 \leq 0,05$. Hasil tersebut menunjukan bahwa Inflasi, DER dan ROA berpengaruh secara simultan dan signifikan terhadap harga saham.

Berdasarkan hasil pengujian pengaruh inflasi (X1) terhadap harga saham (Y2) yang ditunjukkan pada Tabel 2 menunjukkan bahwa inflasi berpengaruh negatif dan signifikan pada harga saham. Ketika inflasi yang tinggi maka biaya operasional perusahaan juga akan tinggi, sehingga estimasi laba yang diperoleh dari perusahaan juga akan menurun. Sahroni dkk. (2017) menyatakan inflasi yang tinggi akan menyebabkan tingginya suku bunga bank. Suku bunga tinggi akan memicu tingginya suku bunga utang yang pada akhirnya akan menurunkan laba bersih perusahaan.

Penurunan pendapatan dan profitabilitas perusahaan mempengaruhi investor untuk berpikir bahwa saham perusahaan tersebut kurang kompetitif, dikarenakan investor tidak tertarik pada perusahan yang tidak membagikan dividen, penurunan harga saham terjadi ketika volume transaksi penawaran dan perintaan terhadap saham perusahaan terebut menurun di pasar modal. Hasil penelitian ini didukung dengan penelitian yang dilakukan sebelumnya oleh Silva (2016); Kusuma dan Badjra (2016); Arifin (2014) dan Subing (2016) menyatakan inflasi memiliki hubungan negatif signifikan dengan harga saham.

Hasil uji dalam penelitin ini ini menunjukkan inflasi berpengaruh negatif dan signifikan terhadap profitabilitas. Semakin besar tingkat inflasi yang ditandai 
dengan naiknya harga-harga barang sehingga dapat menurunkan volume produksi perusahaan yang akan dapat menurunkan tingkat laba atau profitabilitas (Asmara dan Suarjaya, 2018).

Pada tahun 2013 sampai dengan tahun 2015 prospek harga batubara mengalami pelemahan dikarenakan Tiogkok yang menjadi importer batubara bagi Indonesia pertumbuhan konsumsi batubaranya menurun, disisi lain volume produksi perusahaan pertambangan batubara di Indonesia menurun dan harga produk batubara di Indonesia mengalami peningkatan yang diakibatkan inflasi pada tahun 2013 yang hampir mencapai 10\%, sehingga pada tahun 2013 sampai dengan 2015 beberapa perusahaan pertambangan batu bara mengalami penurunan profitabilitas. Hasil penelittian ini didukung oleh temuan penelitian sebelumnya yang dilakukan oleh Hooshyari dan Moghanloo (2015); Lindayanti dan Dewi (2015); Duraj dan Moci (2015) menyatakan inflasi berpengaruh negatif signifikan terhadap profitabilitas.

Berdasarkan hasil pengujian pengaruh struktur modal (X2) terhadap harga saham (Y2) yang ditunjukkan pada Tabel 2. menunjukkan struktur modal berpengaruh negatifr dan signifikan terhadap harga saham. Secara umum, semakin besar angka DER dianggap perusahaan tersebut memiliki risiko finansial (Wiagustini, 2014:85). DER yang besar berarti perusahaan tersebut membiayai investasinya dengan komposisi hutang yang lebih banyak dibandingkan dengan modal, sehingga perusahaan memiliki kewajiban yang harus dipenuhi perusahaan terhadap pihak luar semakin besar, baik berupa pokok maupun bunga pinjaman 
dan juga akan timbul resiko perusahaan tersebut gagal membayar kewajibanya dan suku bunga yang tinggi akan mengurangi profit perusahaan.

Investor cenderung tidak tertarik berinvestasi pada perusahaan yang profitabilitasnya menurun, sehingga akan menurunkan harga saham. Hasil penelitian ini sejalan dengan penelitian yang dilakukan oleh Abditama dan Damayanti (2015); serta Ginting dan Munthe (2017) dimana dinyatakan struktur modal berpengaruh negatif signifikan terhadap harga saham.

Hasil dalam penelitian ini menunjukkan bahwa struktur modal berpengaruh negatif sigifikan terhadap profitabilitas. Perusahaan yang komposisi hutangnya lebih dominan dibandingkan ekuitasnya cenderung memiliki resiko yang lebih tinggi, resiko yang tinggi akan menurunkan laba perusahaan (Sahroni dkk., 2017). Semakin tinggi DER menyebabkan semakin besar beban perusahaan terhadap kreditur, apabila hal tersebut terjadi, maka akan berdampak pada menurunnya perolehan profitabilitas perusahaan.

Teori trade-off menyatakan penggunaan utang yang melampaui batas optimal, karena beban bunga lebih besar daripada manfaat yang diberikan dari pengunaan hutang sehingga keuntungan perusahaan menjadi menurun. Penelitian ini sejalan dengan penelitian yang dilakukan oleh Ashraf dkk., (2017); Ulzanah dan Murtaqi (2015) menemukan bahwa strukur modal berpengaruh negatif signifikan terhadap profitabilitas.

Penelitian ini menunjukkan bahwa profitabilitas berpengaruh positif sigifikan terhadap harga saham, Rasio Profitabilitas adalah rasio yang bertujuan untuk mengetahui kemampuan perusahaan menghasilkan laba selama periode 
I Made Ivan Adiwinata, Peran Profitabilitas Dalam...

tertentu dan memberikan gambaran umum tentang efektivitas manajemen dalam menjalankan operasinya. Efektivitasnya bisa dilihat dari keuntungan yang dihasilkan pada penjualan dan investasi perusahaan (Hanafi, 2012:42).

Meningkatnya ROA suatu perusahaan, menandakan akan semakin tinggi pula nilai aset perusahaan dan menyebabkan harga saham lebih tinggi, dikarenakan nilai ROA yang tinggi akan menarik minat investor untuk berinvestasi, ssehingga akan meningkatkan harga saham, ini berarti bahwa aset perusahaan dapat mempengaruhi harga saham. Hasil penelitian ini didukung oleh hasil penelitian sebelumnya dari Kohansal dkk. (2013); Murniati (2016); Haque dan Faruquee (2013); Dwisona dan haryanto (2015) yang menunjukkan bahwa profitabilitas memiliki pengaruh positif dan signifikan terhadap harga saham.

Pengaruh variabel inflasi (X1) terhadap variabel harga saham (Y2) dengan variabel profitabilitas (Y1) sebagai variabel mediasi, sebagai berikut:

Pengaruh tidak langsung $=$ Px1y1 $\mathrm{x}$ Py1y2

$$
\begin{aligned}
& =-0,621 \times 0,420 \\
& =-0,261
\end{aligned}
$$

Pengaruh variabel struktur modal (X2) terhadap variabel harga saham (Y2) dengan variabel profitabilitas (Y1) sebagai variabel mediasi, sebagai berikut:

Pengaruh tidak langsung $=\mathrm{Px} 2 \mathrm{y} 1 \mathrm{x}$ Py1 $\mathrm{y} 2$

$$
\begin{aligned}
& =-0,3887 \times 0,420 \\
& =-0,163
\end{aligned}
$$


Pengaruh variabel inflasi (X1) terhadap variabel harga saham (Y2) melalui variabel profitabilitas (Y1), sebagai berikut:

Pengaruh total $=$ Px $1 \mathrm{y} 2+(\mathrm{Px} 1 \mathrm{y} 1 \mathrm{x}$ Py1y2 $)$

$$
\begin{aligned}
& =-0,619+(-0,261) \\
& =-0,880
\end{aligned}
$$

Pengaruh variabel struktur modal (X2) terhadap variabel harga saham (Y2) melalui variabel profitabilitas (Y1), sebagai berikut:

Pengaruh total $=\mathrm{Px} 2 \mathrm{y} 2+(\mathrm{Px} 2 \mathrm{y} 1 \times \mathrm{Py} 1 \mathrm{y} 2)$

$$
\begin{aligned}
& =-0,253+(-0,163) \\
& =-0,416
\end{aligned}
$$

Menguji nilai koefisien determinasi $\left(\mathrm{R}^{2}\right)$ dan standard error (e) sebagai berikut:

$$
\begin{aligned}
e & ={\sqrt{1-R^{2}} \ldots \ldots}^{2} 1 \\
& =\sqrt{1-R 1^{2}} \\
& =\sqrt{1-0,512} \\
& =0,698 \\
\mathrm{e} 2 & =\sqrt{1-\mathrm{R}^{2}} \ldots \\
& =\sqrt{1-0,995} \\
& =0,071
\end{aligned}
$$

Standard error telah dihitung, maka didapatkan hasil pengaruh error1 sebesar 0,698 dan pengaruh error2 sebesar 0,071. Perhitungan nilai koefisien determinasi total adalah sebagai berikut :

$$
\begin{aligned}
\mathrm{R}^{2} \mathrm{~m} & =1-\left(\mathrm{Pe}_{1}\right)^{2}\left(\mathrm{Pe}_{2}\right)^{2} \ldots \ldots . . \\
& =1-(0,698)^{2}(0,071)^{2}
\end{aligned}
$$


$=1-(0,487)(0,005)$

$=1-0,034$

$=0,966$

Nilai koefisien determinasi total sebesar 0,966 yang berarti bahwa sebesar 96,6 persen variasi harga saham dipengaruhi oleh inflasi, DER dan ROA, sedangkan sisanya sebesar 3,4 persen dijelaskan oleh faktor lain yang tidak dimasukkan ke dalam model.

Perhitungan pengaruh inflasi terhadap harga saham yang dimediasi oleh profitabilitas adalah sebagai berikut:

$$
\begin{aligned}
& Z=\frac{a_{1} b}{\sqrt{a_{1}^{2} s_{b}^{2}+b^{2} s a_{1}^{2}+s a_{1}^{2} s_{b}^{2}}} \\
& \text { Keterangan: } \\
& \mathrm{a}_{1}=-0,210 \\
& \mathrm{Sa}_{1}=0,026 \\
& \mathrm{~b}=0,400 \\
& \mathrm{Sb}=0,010 \\
& \mathrm{Z}=\frac{(-0,210)(0,400)}{\sqrt{(-0,210)^{2}(0,010)^{2}+(0,400)^{2}(0,026)^{2}+(0,026)^{2}(0,010)^{2}}} \\
& Z=\frac{-0,084}{\sqrt{(0,00000441)+(0,00011)+(0,0000000676)}} \\
& \mathrm{Z}=\frac{-0,084}{0,011} \\
& z=-7,63
\end{aligned}
$$

Berdasarkan hasil uji sobel dalam penelitian ini menunjukkan bahwa hasil tabulasi $Z=-7,63>1,96$. Hasil tersebut memiliki arti bahwa profitabilitas mampu memediasi pengaruh inflasi terhadap harga saham. 
Perhitungan pengaruh struktur modal terhadap harga saham yang dimediasi oleh profitabilitas

$$
\begin{aligned}
& \mathrm{Z}=\frac{\mathrm{a}_{2} \mathrm{~b}}{\sqrt{\mathrm{a}_{2}^{2} \mathrm{~s}_{\mathrm{b}}^{2}+\mathrm{b}^{2} \mathrm{sa}_{2}^{2}+\mathrm{sa}_{2}^{2} \mathrm{~s}_{\mathrm{b}}^{2}}} \ldots \ldots \ldots \ldots \ldots \ldots \ldots \ldots \ldots \ldots \ldots \ldots \ldots \ldots \ldots \ldots \ldots \ldots \ldots \ldots \ldots \\
& \text { Keterangan: } \\
& \mathrm{a}_{2}=-0,321 \\
& \mathrm{Sa} \mathrm{a}_{2}=0,064 \\
& \mathrm{~b}=0,400 \\
& \mathrm{Sb}=0,010 \\
& \mathrm{Z}=\frac{(11)}{\sqrt{(-0,321)^{2}(0,010)^{2}+(0,400)^{2}(0,064)^{2}+(0,064)^{2}(0,010)^{2}}} \\
& \mathrm{Z}=\frac{-0,1284}{\sqrt{(0,0000103)+(0,000655)+(0,00000041)}} \\
& \mathrm{Z}=\frac{-0,1284}{0,0258} \\
& \mathrm{Z}=-4,98
\end{aligned}
$$

Berdasarkan hasil uji sobel dalam penelitian ini menunjukkan bahwa hasil tabulasi $Z=-4,98>1,96$. Hasil tersebut memiliki arti bahwa profitabilitas memediasi pengaruh struktur modal terhadap harga saham.

Berdasarkan hasil analisis jalur, dapat disimpulkan bahwa profitablitas mampu memediasi secara signifikan pegaruh inflasi terhadap harga saham, dengan nilai pengaruh langsung -0,619 lebih kecil dari pengaruh totalnya sebesar $-0,880$ setelah ditambahakanya pegaruh tidak langsung sebesar $-0,261$. Hasil uji sobel juga menunjukkan nilai Z -7,63 lebih besar dari 1,96. Hasil ini menunjukkan bahwa ROA berperan sebagai variabel mediasi inflasi terhadap harga Saham, 
inflasi tetap memiliiki pengaruh yang negatif terhadap harga saham, walaupun telah melalui ROA.

Inflasi yang meningkat maka perusahaan akan mengalami dampak pada penurunan profitabilitas yang berakibat pada penurunan harga saham, hal ini dikarenakan biaya produksi perusahaan akan meningkat dikarenakan harga kebutuhan pokok dan bahan baku produksi meningkat. Perusahaan akan menurunkan volume produksinya sehingga bedampak pada penurunan kemampuan perusahaan menghasilkan laba, investor cenderung tidak tertarik berinvestasi pada perusahaan yang mengalami penurunnan laba, sehingga mengakibatkan penurunan harga saham.

Dari paparan diatas dapat disimpulkan bahwa inflasi akan berpengaruh negatif terhadap harga saham apabila di mediasi oleh nilai ROA perusaahaan. dengan kata lain dapat dinyatakan bahwa dengan penurunan tingkat inflasi maka akan dapat meningkatkan profitabilitas yang juga diikuti dengan meningkatnya harga saham perusahaan. Hasil penelitian ini sejalan degan penelitian yang dilakukan oleh Winarti (2018) dan A'yun (2017) menyatakan profitabilitas mampu memediasi pengaruh inflasi terhadap harga saham.

Berdasarkan hasil analisis jalur, dapat disimpulkan profitabilitas mampu memediasi secara signifiikan pengaruh struktur modal terhadap harga Saham, dengan nilai pengaruh langsung sebesar $-0,253$ dan pengaruh tidak langsung sebesar -0,163, serta pegaruh total sebesar -,0416. Hasil uji sobel menunjukkan nilai Z -4,98 lebih besar dari 1,96. Hasil ini menunjukkan bahwa DER memiliki 
pengaruh negatif yang lebih besar terhadap harga saham ketika memasukan nilai ROA sebagai variabel mediasi.

Perusahaan yang menggunakan hutangnya secara optimal akan menghasilkan profit yang semakin meningkat jika dibandingkan menggunakan modalnya sendiri. Penggunaan hutang dalam sumber pendanaan memiliki manfaat, seperti dapat mengurangi jumlah pembayaran pajak karena beban bunga tetap dapat mengurangi pembayaran pajak, namun apabila perusahaan tiak mampu mengoptimalkan hutangnya untuk operasional perusahaan, maka perusahaan akan mengalami penurunan profitabilitas. dikarenakan laba yang diperoleh digunakann untuk membayar beban bunga sehingga laba bersih yang diperoleh menurun, perusahaan denngan nilai DER yang tinggi juga memiiki resiko gagal bayar, umumya investor di pasar modal cenderung menghidari perusahaan dengan nilai DER yang tinggi, hal ini akan menyebabkan penurunan harga saham.

Hasil penelitian ini didukung oleh hasil penelitan sebelumya yang dilakukan oleh Misran dan Chabacib (2017); Hamidy dkk. (2015); Dwisona dan haryanto (2015) menyatakan profitabilitas mampu memediasi pengaruh struktur modal terhadap harga saham

\section{SIMPULAN DAN SARAN}

Inflasi berpengaruh negatif signifikan terhadap harga saham. Inflasi berpengaruh negatif dan signifikan terhadap profitabilitas. Struktur Modal berpengaruh negatif dan signifikan terhadap harga saham. Struktur modal berpengaruh negatif dan signifikan terhadap profitabilitas. Profitabilitas berpengaruh positif dan signifikan terhadap harga saham. Profitabilitas mampu 
I Made Ivan Adiwinata, Peran Profitabilitas Dalam...

memediasi pengaruh inflasi terhadap harga saham. Profitabilitas mampu memediasi pengaruh struktur modal terhadap harga saham.

Bagi perusahaan hendaknya hasil penelitian ini dapat menjadi bahan pertimbangan untuk meningkatkan kinerja dan laba bersih yang dihasilkan perusahaan dengan memperhatikan tingkat inflasi dan penggunaan hutang jangka pendek maupun jangka panjang dan modal sendiri. Karena inflasi dan hutang yang tidak dioptimalkan perusahaan dengan baik akan menurunkan laba perusahaan, yang akan berdampak pada menurunya harga saham.

Bagi investor penelitian ini diharapkan dapat memberikan infomasi mengenai pengaruh inflasi, struktur modal dan profitabilitas perusahaan terhadap harga saham yang menjadi bahan pertimbangan dalam membuat keputusan investasi.

Bagi peneliti selanjutnya yang ingin meneliti mengenai harga saham, tambahkan variabel ekonomi makro dan rasio kinerja keuangan yang lain sehingga didapatkan indikator lain yang memiliki hubungan dengan harga saham, serta mengembangkan penelitian ini dengan memperluas bagi ruang lingkup dan jenis perusahaan yang berbeda serta hasil dari penelitian ini dapat dijadikan pedoman dalam melakukan penelitian selanjutnya dan dapat dijadikan sebagai sumber informasi bagi masyarakat luar.

\section{REFERENSI}

Abditama, dan Damayanti. (2015). The Influence of Company Performance toward Stock Price of PT. XL Axiata TBK. Journal bussnies and management, Vol. 4, No.4, 510-521. 
Ashraf, Ameen, Kiran Shazandi. (2017). The Impact of Capital Structure on Firm's Profitability: A Case of Cement Industry of Pakistan. International Journal of Business and Social Science,Vol 8, No. 4. 140-147.

Asmara, dan suarjaya. (2018). Pengaruh Variabel Ekonomi Terhadap IHSG. EJurnal Manajemen Unud, Vol. 7, No. 3, 1397-1425.

A'yun, Inoratul. (2017). Pengaruh variabel fundamental dan makroekonomi terhadap harga saham melalui roa (studi pada perusahaan yang tergabung dalam jakarta islamic index). Tesis. Universitas islam negeri maulana malik Ibrahim Malang

Bonatua, Suhadak, Endang. (2015). Pengaruh Struktur Modal Terhadap Profitabilitas (Studi Pada Perusahaan Manufaktur Sub Sektor Food and Beverage Yang Listed di BEI Periode 2010-2013). Jurnal Administrasi Bisnis (JAB), Vol. 2 No. 2. 1-7.

Damar, Faruk, Winarto. (2015). Analysis Of The Effect Of Financial Leverage And Liquidity Toward Stock Value And Profitability As The Intervening Variabel In Trading Companies Listed at Indonesia Stock Exchange 20102014. jurnal polines. Vol. 1, No. 2.

Dewi, Artini. (2016). Pengaruh Suku Bunga SBI Dan Inflasi, Serta Fundamental Perusahaan Terhadap Harga Saham Pada Perusahan Indeks LQ45 Di BEI. E-Jurnal Manajemen Unud. Vol. 5, No. 4. 2484-2510.

Duraj, dan Moci. (2015). Factors Influencing The Bank Profitability - Empirical Evidence From Albania. Asian Economic and Financial Review, Vol. 5, No. 3, 483-494.

Dwisona, Haryanto. (2015). Analisis pengaruh faktor fundamental terhadap harga saham dengan roa sebagai variabel intervening pada perusahaan LQ45 periode 2010-2013. Diponegoro journal of management. Vol. 4, No. 3. 113.

Hamidy, Wiksuana dan Artini. (2015). Pengaruh Struktur Modal Terhadap Nilai Perusahaan Dengan Profitabilitas Sebagai Variabel Intervening Pada Perusahaan Properti Dan Real Estate Di Bursa Efek Indonesia. E-Jurnal Ekonomi dan Bisnis Universitas Udayana, Vol. 4, No.10. 665-682

Hanafi, M. Mamduh. (2012). Manajemen Keuangan. Yogyakarta: BPFE.

Haque, and Faruquee. (2013). Impact of Fundamental Factors on Stock Price: A Case Based Approach on Pharmaceutical Companies Listed with Dhaka Stock Exchange. International Journal of Business and Management Invention, Vol. 12. No. 9. 34-41. 
Hooshyari, dan Moghanloo. (2015). Evaluating The Impact Of Inflation On Profitability Of Banks. Kuwait Chapter of Arabian Journal of Business and Management Review. Vol. 4, No. 9. 19-23

Irham, Fahmi, (2015). Manajemen Investasi Teori dan Soal Jawab. Edisi 2. Salemba Empat, Jakarta.

Kalengkongan, Glenda. (2013). Tingkat Suku Bunga Dan Inflasi Pengaruhnya Terhadap Return On Asset (Roa) Pada Industri Perbankan Yang Go Public Di Bursa Efek Indonesia. Jurnal EMBA, Vol.1, No.4. 737-747

Kasmir. (2011). Analisis Laporan Keuangan.Jakarta: Rajawali Pers

Kohansal, Amir, Karmozdi dan Mohseni. (2013). Relationship between Financial Ratios and Stock Prices for the Food Industry Firms in Stock Exchange of Iran. World Applied Programming, Vol. 3, No. 10. 512-521.

Kusuma, dan Badjra. (2016). Pengaruh Inflasi, Jub, Nilai Kurs Dollar Dan Pertumbuhan Gdpterhadap Ihsg Di Bursa Efek Indonesia. E-Jurnal Manajemen Unud, Vol.5, No. 3, 1829-1858.

Lindayani, dan Sutrisna Dewi. (2016). Dampak Struktur Modal dan Inflasi terhadap Profitabilitas dan Return Saham pada Perusahaan Keuangan Sektor Perbankan. E-Jurnal Manajemen Unud, Vol. 5, No.8, 5274-5303.

Mahardhika, dan Marbun. (2016). Pengaruh Current Ratio Dan Debt To Equity Ratio Terhadap Return On Assets. Widyakala. Vol. 3. 23 - 28.

Misran, Medy dan Chanacib. (2017). Analisis Pengaruh Der Cr Dan Tato Terhadap Pbv Dengan Roa Sebagai Variabel Intervening (Studi Pada Perusahaan Properti Dan Real Estate Yang Terdaftar Pada Bei Tahun 2011 - 2014). Diponegoro Journal Ofmanagement. Vol. 6, No. 1. 203-215

Murniati,sitti. (2016). Effect of Capital Structure, Company Size and Profitability on the Stock Price of Food and Beverage Companies Listed on the Indonesia Stock Exchange. Information Management and Business Review, Vol. 8, No. 1, 23-29. Moeslim Indonesian University

Purnama, dan Purbawangsa. (2015). Pengaruh Kinerja Keuangan Dan Variabel Makro Ekonomi Terhadap Harga Saham Perusahaan Pertambangan. EJurnal Manajemen Unud, Vol. 6, No. 4, 1729-1760.

Purwitasari, dan Septiani. (2013). Analisis pengaruh struktur modal terhadap profitabilitas (studi empiris pada perusahaan manufaktur yang terdaftar di 
bei tahun 2009-2011). Diponegoro journal of accounting. Vol. 2, No. 3. $1-11$

Rani, dan diantini. (2015). Pengaruh Kinerja Keuangan Perusahaan Terhadap Indeks Harga Saham Perusahaan LQ45 Yang Terdaftar di BEI. E-Jurnal Manajemen Unud, Vol. 4, No. 6, 1504-1524.

Sahroni, Zulfitra, Harifah, (2017). Determinant of Stock Price : A Empirical Study at State Owned Enterprises in Indonesia. International Journal of Applied Business and Economic Research. Economic Faculty of Universitas Pamulang, Vol. 15, No 20. 1-10

Silva, N.L.C. (2016). Effect of Inflation on Stock Prices: Evidence from Sri Lanka. International Journal of Scientific \& Engineering Research, Vol. 7. No. 4. $16-38$

Tandelilin, Eduardus. (2010). Portofolio dan Investasi Teori dan Aplikasi, Edisi Pertama. Kanisius IKAPI Yogyakarta.

Ulzanah, \& Murtaqi. (2015). The Impact Of Earnings Per Share, Debt To Equity Ratio, And Current Ratio Towards The Profitability Of Companies Listed In LQ45. Journal of Business and Management, Vol.4, No.1. 18-27.

Velnampy, dan Niresh. (2012). The Relationship between Capital Structure \& Profitability. Global Journal of Management and Business Research. Vol. 12, No. 13. 67-74.

Wiagustini, Ni Luh Putu. (2014). Manajemen Keuangan. Udayana Press

Winarti. (2018). Pengaruh Nilai Tukar Rupiah, Inflasi, Tingkat Suku Bunga Terhadap Harga Saham Dengan Profitabilitas Sebagai Variabel Intervening Pada Perusahaan Indeks Lq -45 Yang Terdaftar Di Bursa Efek Indonesia. Tesis. Fakultas Ekonomi Universitas 17 Agustus 1945 Surabaya. 